\title{
Pharmacognostical and Physicochemical Studies of Enhalus acoroides (L.F.) Royle (Rhizome)
}

\author{
Supattra Klangprapun', Benjaporn Buranrat ${ }^{1}$, Wanida Caichompoo ${ }^{2}$, Somsak Nualkaew ${ }^{2, *}$
}

\section{Supattra Klangprapun', Benjaporn Buranrat ${ }^{1}$, Wanida Caichompoo ${ }^{2}$, Somsak Nualkaew ${ }^{2, *}$}

'Faculty of Medicine, Mahasarakham University, Mahasarakham, THAILAND. 2Pharmaceutical Chemistry and Natural Product Research Unit, Faculty of Pharmacy, Mahasarakham University, Mahasarakham, THAILAND.

\section{Correspondence}

\section{Dr. Somsak Nualkaew}

Pharmaceutical Chemistry and Natural Product Research Unit, Faculty of Pharmacy, Mahasarakham University, Mahasarakham, THAILAND.

Phone no: +66-85-1376763

E-mail: somsak.n@msu.ac.th

\section{History}

- Submission Date: 24-07-2018;

- Review completed: 05-09-2018;

- Accepted Date: 04-10-2018

\section{DOI : 10.5530/pj.2018.6s.17}

Article Available online http://www.phcogj.com/v10/i6s

\section{Copyright}

(c) 2018 Phcog.Net. This is an openaccess article distributed under the terms of the Creative Commons Attribution 4.0 International license.

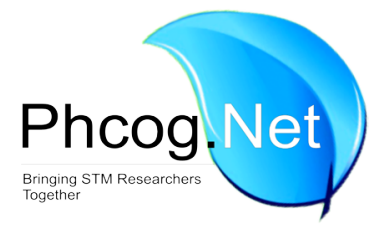

\begin{abstract}
Introduction: The rhizome of Enhalus acoroides (L.f.) Royle is used in traditional medicine for treatment of many diseases e.g. muscle pains, wounds and stomach problems where pharmacognostical studies are lacking. Many chemical constituents; luteolin, apigenin, luteolin glycosides, stigmasterol, daucosterol have been reported. The aim of this work was to perform a pharmacognostical evaluation. Methods: Macroscopical, microscopical and physicochemical parameters were assessed. Results: E. acoroides has characteristic morphology. Microscopical studies indicated the presence of vessels, fiber, parenchyma cells, sclereids, tracheids and trichomes. Physicochemical parameters of E. acoroides rhizome; foreign matter, loss on drying and total ash content were measured. As well as chemical investigation through TLC and HPLC were specified. Conclusion: The present study of E. acoroides rhizome provides useful information that can serve as a diagnostic tool for the standardization of E. acoroides and will be helpful in characterization of the crude drug in the market. Key words: Enhalus acoroides, Macroscopic, Microscopic, Pharmacognostic, Standardization, Specification.
\end{abstract}

\section{INTRODUCTION}

Enhalus acoroides (L.f.) Royle is a seagrass, in a monotypic genus of marine flowering plants belonging to the family of Hydrocharitaceae. E. acoroides is wide spread in the Indian to Pacific Oceans. ${ }^{1}$ There are approximately 50 species of seagrasses in 12 genera around the world and E. acoroides is common in the major seagrass areas of Southeast Asia. ${ }^{2}$ In Thailand, it is one of twelve seagrass species are found in 19 provinces. $^{3}$ It occurs in brackish water canals down to the lower intertidal and subtidal zones on mud, muddy sand and sandy coral substrates. In the gulf of Thailand, it grows on coarse substrate ranging from medium and coarse sand to coral rubble at a depth of 0.5-1.0 m. ${ }^{4}$

Many studies have shown the benefits of E. acoroides. It has long been recognized as critical coastal nursery habitat for estuarine fisheries and wildlife. It functions as direct food sources for fish, waterfowl, dugongs, manatees and sea turtles. It also participants in nutrient cycling processes and acts as a stabilizing agent in coastal sedimentation and erosion processes. ${ }^{5-7}$ The seeds of E. acoroides have been traditionally eaten in the Philippines. The raw seeds are described as crunchy and sweet while boiled seeds contained more starch and taste like cooked sweet potato. ${ }^{8}$ In folk medicine, it has been used for a variety of remedial purposes, e.g. for the treatment of fever and skin diseases, muscle pains, wounds, stomach problems, a remedy against stings of different kinds of rays and tranquillizers for babies. ${ }^{9}$ In India, it was used for treatment of heart conditions and sea sickness. Seeds of E. acoroides are thought to have aphrodisiac and contraceptive properties. ${ }^{10} \mathrm{~A}$ number of traditional Maluku coastal residents believe that seed of E. acoroides is able to promote the immune system. ${ }^{11}$ In Thailand, only rhizome of $E$. acoroides was used as a medicine for treatment of carminative and to increase blood and lymph circulation. ${ }^{12-13}$ It is used in many recipes of Thai traditional medicine e.g. Maha-Anan-Ta-Khun, Ya-Kae-Sama-That, Prab-Chom-Phu-Tha-Weep. ${ }^{14-15}$ Pharmacological activities of extracts and isolated compounds of E. acoroides have been reported including antioxidant, ${ }^{10-11}$ antifeedant, antibacterial, antilarval, anti-inflammatory and antidiabetic activity. ${ }^{10,16}$ Rough extract of E. acoroides that contains polysaccharide and other substances has been shown to have antiviral (CVB3, HSV-1) and antibacterial activities and to activate insulin secretion. ${ }^{11}$ Many chemical compounds of E. acoroides have been studied. The seeds are highly nutritious as they contain carbohydrate $(59.26 \%)$, protein $(5.65 \%)$ and fat $(0.76 \%) .{ }^{11}$ Fresh leaves of E. acoroides are rich in the sterol and fatty acid components; sitosterol, stigmasterol, palmitic acid, linoleic acid, linolenic acid and stigmasterol derivatives. ${ }^{16-18}$ The rhizome and roots of $E$. acoroides contain many chemical constituents such as luteolin, apigenin, luteolin 4'-glucuronide,

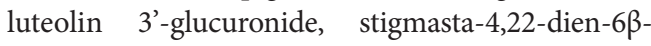
ol-3-one, stigmasta-4,22-dien-3,6-dione, stigmast-

Cite this article: Klangprapun S, Buranrat B, Caichompoo W, Nualkaew S. Pharmacognostical and Physicochemical Studies of Enhalus acoroides (L.F.) Royle (Rhizome). Pharmacog J. 2018;10(6) Suppl:s89-s94. 
22-en-3-one, stigmasta-5,22-dien-3-O- $\beta$-D-glucopyranoside, daucosterol, hexacosyl alcohol, $p$-hydroxy-benzaldehyde, $n$-hexadecanoic acid..$^{10,16}$

Although much information about E. acoroides has been reported, pharmacognostical studies are lacking. The objectives of the present study were to evaluate pharmacognostical parameters of the E. acoroides including macroscopic, microscopic and physicochemical properties to establish a standard for quality control of crude drug of E. acoroides.

\section{MATERIALS AND METHODS}

\section{Plant material}

The dried rhizome of $E$. acoroides were collected from 19 traditional drug stores located in different regions throughout Thailand. The fresh plant of E. acoroides (authentic samples) were collected from Phrathong island (Phangnga province), Samui island (Suratthani province), Yaoyai island (Trang province) and Tharai island (Nakhonsrithammarat province), Thailand. The authentic samples were identified by Dr. Sutthira Sedlak, the botanist of Walairukhavej Botanical Research Institute, Mahasarakham University, Thailand. The rhizomes were cut and washed with water to remove the adherent impurities, dried in a hot air oven at $40^{\circ} \mathrm{C}$ for $48 \mathrm{~h}$. The voucher specimens were deposited at Faculty of Pharmacy, Mahasarakham University, Thailand (Code: MSU.PH-HDT-C1). The dried rhizomes of $E$. acoroides from each sample (1000 g) were kept in air tight containers until used. Another $1000 \mathrm{~g}$ of dried rhizomes from each resource were ground to a coarse powder (sieve No.70) and stored in air tight containers until used.

\section{Chemical}

Organic solvents (AR grade), chloroform, dichloromethane, ethyl acetate, ethanol, hexane and methanol were obtained from RCI Labscan (Thailand) and toluene from CARLO ERBA, Italy. Hydrochloric acid and sulfuric acid were purchased from CARLO ERBA, Italy, formic acid from Merck, Germany and trifluoroacetic acid from Fisher chemical, UK. Anisaldehyde was purchased from Panreacquimica, Spain. Ultra-gradient acetonitrile (ACN) used in HPLC was obtained from RCI Labscan (Thailand). Reference substances, apigenin and luteolin were purchased from Sigmaaldrich, USA and daucosterol from Chengdu biopurify phytochemical, China. TLC plate, silica gel $\mathrm{GF}_{254}$ was purchased from Merck, Germany.

\section{Pharmacognostical studies \\ Macroscopical evaluation}

The following macroscopical characters of the whole plant and rhizome of samples were noted; size and shape, color, surfaces, texture, odor and taste. $^{19}$

\section{Microscopical evaluation}

The powdered rhizome of $E$. acoroides was studied under the microscope by the following methods. A small quantity of powder was placed on slides and mounted with 2-3 drops of chloral hydrate and covered with a cover slip then examined under the microscope. Different cell components i.e. fibers, lignified fibers, cortex cells, calcium oxalate crystals and stomata cells were noted and photographed using a digital camera with Material Science Software, Axio Vision, Carl Zeiss.

\section{Chemical identification}

Chemical identification were done by Thin layer chromatography (TLC) and high performance liquid chromatography (HPLC). For TLC, the silica gel $\mathrm{GF}_{254}$ was used as the stationary phase. Two solutions, daucosterol standard $(1 \mathrm{mg} / \mathrm{mL}$ in ethanol) and dichloromethane extract of E. acoroides were applied to the plate. The TLC were developed in a glass chamber containing toluene: ethyl acetate: methanol: formic acid (3: $4: 1: 1) \mathrm{v} / \mathrm{v}$ as the mobile phase. The plates were removed after the solvent front has moved from the original position to the finish line $(8 \mathrm{~cm})$ and subsequently allowed to dry. After drying, the plate was examined under ultraviolet light (254 and $366 \mathrm{~nm}$ ) and sprayed with anisaldehyde-sulfuric acid spray reagent. The distance components of a mixture travelled were quantified using retention factors. ${ }^{20}$

HPLC analysis was achieved using a chromatographic system (Primaide, Hitachi) equipped with diode array detector determined at $254 \mathrm{~nm}$. Analytical column HPLC, Phenomenex (Kinetex C18, 100x4.6 mm, $2.6 \mathrm{~mm}$ ) was used. The gradient of acetonitrile and $0.05 \%$ trifluoroacetic acid in water were used as the mobile phase to find a suitable condition. Apigenin $(1 \mathrm{mg} / \mathrm{mL}$ in ethanol) and luteolin $(1 \mathrm{mg} / \mathrm{mL}$ in methanol) were used as the reference substances. Two gram of $E$. acoroides was extracted with $25 \mathrm{~mL}$ of $80 \%$ ethanol in ultrasonic bath for $30 \mathrm{~min}$ and filtered by $0.45 \mu \mathrm{m}$ membrane filter before injection to HPLC.

\section{Determination of physicochemical parameters}

Physicochemical parameters were examined following the WHO and Thai herbal pharmacopoeia guidelines including foreign matter, loss on drying, total ash, acid-insoluble ash and water, ethanol, chloroform and hexane soluble extractives. ${ }^{19,21}$

\section{Foreign matter}

The $250 \mathrm{~g}$ of dried rhizome of E. acoroides were spread on white, clean muslin cloth. Foreign matter was sorted out by visual inspection. The portions of the sorted foreign matter were weighed and the percent content of foreign matter of the sample was calculated.

\section{Loss on drying}

About $2.0 \mathrm{~g}$ of E. acoroides rhizome powder was accurately weighed in wide mouthed flat weighing bottles. The bottles were placed in an air oven, maintained at $105 \pm 2^{\circ} \mathrm{C}$, for $2 \mathrm{~h}$. The bottles were then removed, covered and placed in a desiccator. The respective bottles were weighed after cooling to room temperature and were reheated until two consecutive weights did not differ by more than $5 \mathrm{mg}$. The percent loss on drying was then calculated.

\section{Total ash}

About $2.0 \mathrm{~g}$ of E. acoroides rhizome powder was accurately weighed in previously dried, tared silica crucibles and incinerated in a muffle furnace by gradually increasing the temperature to $450^{\circ} \mathrm{C}$ until a white carbon free ash was formed. The silica crucibles were then cooled in a desiccator and weighed. The percent total ash content was then calculated.

\section{Acid insoluble ash value}

The ash obtained from the total ash was boiled in $25 \mathrm{ml}$ of dilute hydrochloric acid $(2 \mathrm{~N} \mathrm{HCl})$ for $5 \mathrm{~min}$, filtered through ashless filter paper and washed with hot water until the filtrate was neutral $\mathrm{pH}$. The filter papers along with the residues were placed in silica crucibles and ignited in a muffle furnace, at $500^{\circ} \mathrm{C}$ for $1 \mathrm{~h}$. The crucibles were cooled and weighed to a constant weight. The percentage of acid insoluble ash was then calculated.

\section{Ethanol soluble extractive}

About $5.0 \mathrm{~g}$ of E. acoroides rhizome powder was accurately weighed and macerated with $100.0 \mathrm{ml}$ of ethanol in a closed flask for $24 \mathrm{~h}$, with frequent shaking during the first $6 \mathrm{~h}$ and then allowed to stand for $18 \mathrm{~h}$ and filtered. The $20 \mathrm{ml}$ of filtered extract was evaporated to dry in a tared china dish at $105^{\circ} \mathrm{C}$. The percentage yield of alcohol soluble extractive with reference to air dried drug was finally calculated for ethanol soluble extractive. 


\section{Water soluble extractive}

The procedures was similar to that used for ethanol extraction except that chloroform water was used instead of ethanol.

\section{Hexane soluble extractive}

About $2.0 \mathrm{~g}$ of E. acoroides rhizome powders was extracted completely with hexane in a soxhlet apparatus by continuous extraction for $20 \mathrm{~h}$. The hexane solution was transferred to a tared porcelain dish and evaporated to dryness. The extract was further dried over silica gel for one hour to constant weight. The percentage yield of hexane soluble extractive was calculated with reference to the air-dried substance.

\section{Chloroform soluble extractive}

The procedure was similar to that used hexane extraction except that chloroform was used instead of hexane.

\section{RESULTS}

\section{Macroscopic characteristics of the fresh E. acoroides}

E. acoroides is the largest seagrass species. It is a perennial plant with underground stems (rhizomes). The leaves are simple, alternate distichous, straight up, flat, very long and ribbon-like 1-2 $\mathrm{cm}$ wide and $30 \mathrm{~cm}-1.5 \mathrm{~m}$ long. It is a dark green color and thick (hard to tear), the margin is entire. Leaf apex is rounded and slightly wavy from damage by grazing herbivores or rough weather. The leaves are palmate with 13-19 parallel venation. A leaf sheath encircles the stem and protect the young leaf. The striking characteristic is the thick rhizome and long, black fibers that are actually remnants of a leaf sheath. The rhizomes are found parallel and perpendicular to the ground and straight up. The roots are robust, large, cordlike, white opaque and numerous $10-20 \mathrm{~cm}$ long and $3-5 \mathrm{~mm}$ wide. The roots grow out of the rhizome. It flowers quite regularly, producing large female flowers on long stalks that develop into a furry fruit. Male inflorescences are composed of a peduncle $5 \mathrm{~cm}$ long, hairy sessile bracts, pedicellate male flowers, oblong white sepals about $2 \mathrm{~mm}$, white petals which are larger than the sepals, white stamens about $1.5-2 \mathrm{~mm}$. Female flower composed of a peduncle $50 \mathrm{~cm}$ long which will coil and contract after anthesis, hairy bracts size $4-6 \times 1-2 \mathrm{~cm}$, reddish sepals, white strap-shaped petals about $4-5 \mathrm{~cm} \times 3-4 \mathrm{~mm}$ with papillose, ovoid ovary with long hairs. Fruit is ovoid, $5-7 \mathrm{~cm}$ in diameter. The seed is angular, $1-1.5 \mathrm{~cm}$ in diameter. ${ }^{22}$ The macroscopical characteristics of the fresh E. acoroides was shown in Figure 1.

\section{Macroscopic characteristics of the dried rhizome of E. acoroides}

The characteristics of $E$. acoroides rhizome are black $0.7-1 \mathrm{~cm}$ thick and 7-10 cm long; clothed with numerous black fibrous strands of decayed leaves and roots. The macroscopical characteristics of the dried E. acoroides rhizome are shown in Figure 2 and crude drug is shown in Figure 3.

\section{Microscopic characteristics}

Microscope examination of dried rhizome powders of E. acoroides revealed the major components to be vessels, fiber, parenchyma cells, sclereids, tracheid and trichome. (Figure 4)

\section{Physicochemical parameters}

Physicochemical variables of $E$. acoroides rhizome investigated were; presence of foreign matter, loss on drying, total ash, acid-insoluble ash, ethanol-soluble extractive, water-soluble extractive, hexane-soluble extractive and chloroform-soluble extractive and are presented in Table 1.

\section{Chemical identification}

The TLC chromatogram of reference standard (daucosterol) and dichloromethane extract of $E$. acoroides rhizome which were detected by UV 254, UV 366 and anisaldehyde-sulfuric acid spray reagent are shown in the Figure 5 and Table 2. The mobile phase used in this study was,

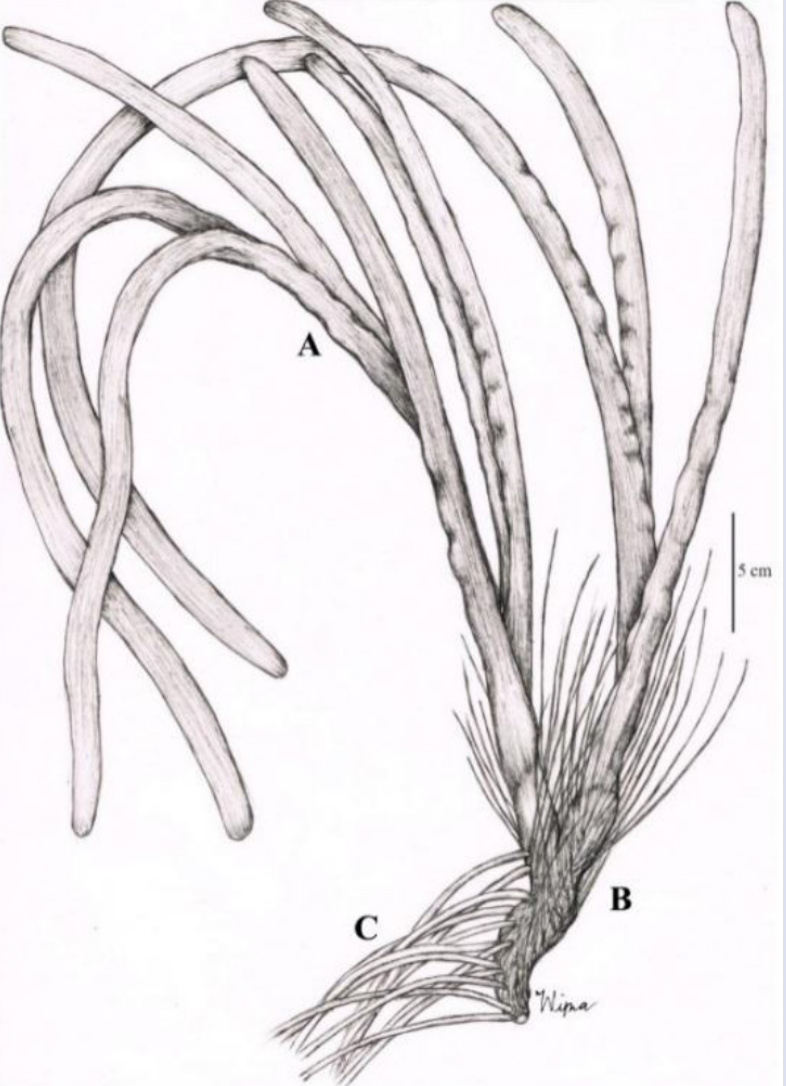

Figure 1: The macroscopical characteristics of fresh E. acoroides; Leaves $(A)$, rhizome $(B)$ and roots $(C)$.

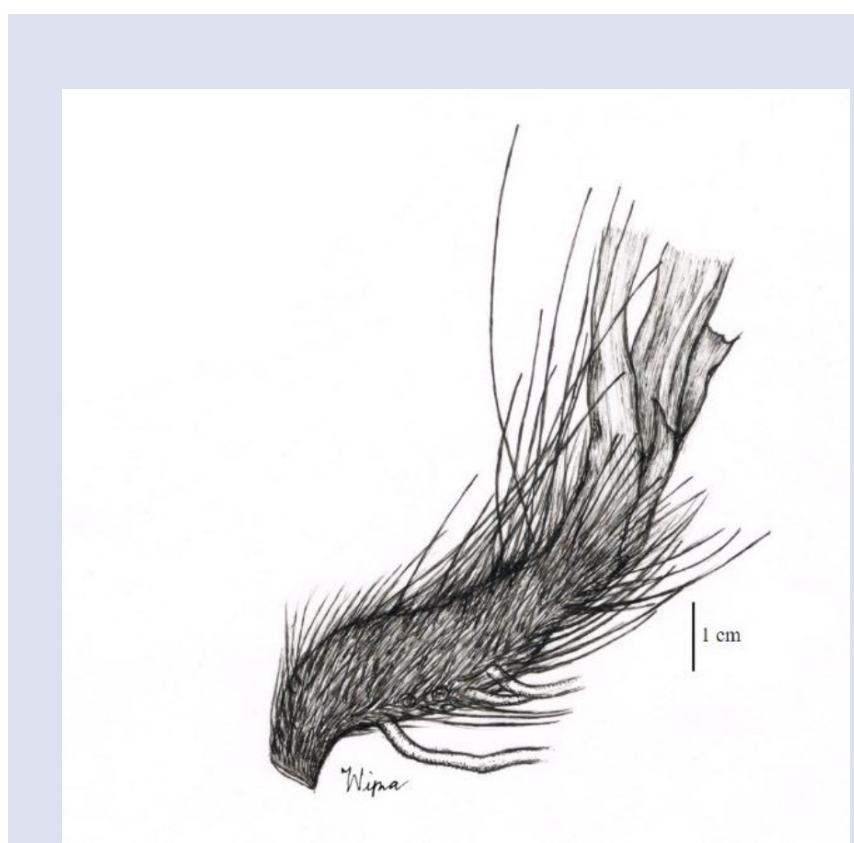

Figure 2: The macroscopical characteristics of dried rhizomes of E. acoroides. 


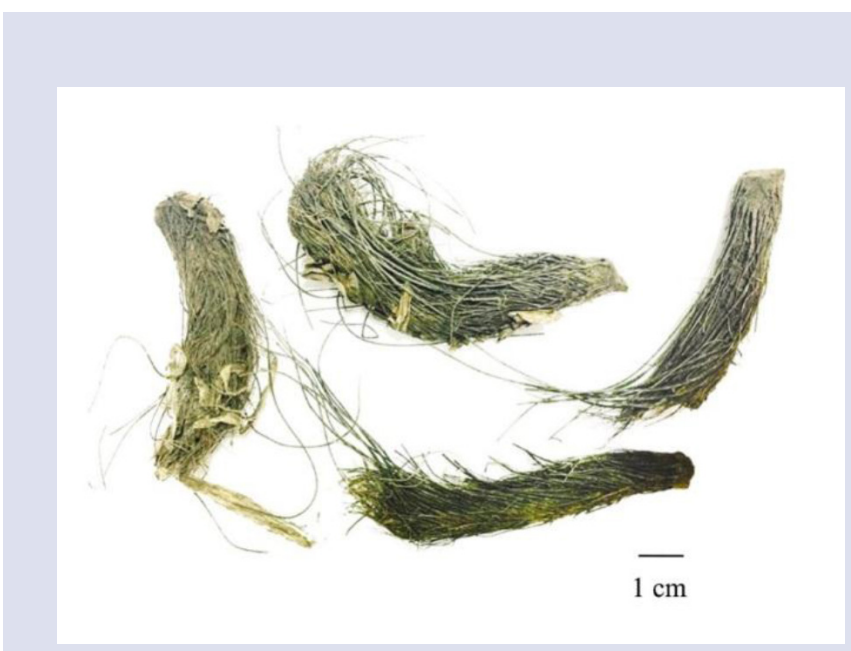

Figure 3: The crude drug of E. acoroides.

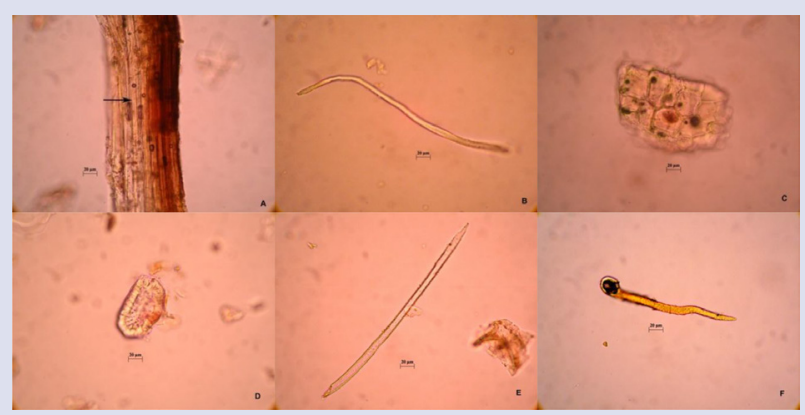

Figure 4: Microscopic characteristic of E. acoroides rhizomes; vessels (A), fiber (B), parenchyma cells (C), sclereid (D), tracheid (E), trichome (F).

Table 1: Specifications of $E$. acoroides rhizomes.

\begin{tabular}{ccc}
\hline Content (\% by weight) & Mean \pm SD & Limitation \\
\hline Foreign matter & $0.22 \pm 0.23$ & Not more than 0.25 \\
Loss on drying & $3.10 \pm 0.95$ & Not more than 3.50 \\
Total ash & $20.55 \pm 3.90$ & Not more than 23.00 \\
Acid-insoluble ash & $5.64 \pm 1.85$ & Not more than 6.20 \\
Ethanol soluble extractive & $2.56 \pm 2.13$ & Not less than 2.30 \\
Water soluble extractive & $16.48 \pm 5.89$ & Not less than 14.80 \\
Hexane soluble extractive & $4.58 \pm 1.53$ & Not less than 4.10 \\
Chloroform soluble extractive & $4.59 \pm 0.43$ & Not less than 4.10 \\
\hline
\end{tabular}

toluene: ethyl acetate: methanol: formic acid (3: 4: 1: 1). The TLC chromatogram obtained from dichloromethane extract under the UV $254 \mathrm{~nm}$ showed 2 quenching spots $\left(\mathrm{hR}_{\mathrm{f}} 60-62\right.$ and $\left.81-83\right)$, while the chromatogram under UV $366 \mathrm{~nm}$ showed 4 spots $\left(\mathrm{hR}_{\mathrm{f}} 21-23,50-52\right.$, 60-62 and 58-59) which $\mathrm{R}_{\mathrm{f}}$ is retardation factor, $\mathrm{hRf}=100 \mathrm{R}_{\mathrm{f}}$. The chromatogram visualized by anisaldehyde-sulfuric acid spray reagent showed 5 spots $\left(\mathrm{hR}_{\mathrm{f}} 2-5,7-8,20-21,50-52\right.$ and $\left.53-56\right)$. Daucosterol gave a purple color with the anisaldehyde-sulfuric acid spray reagent

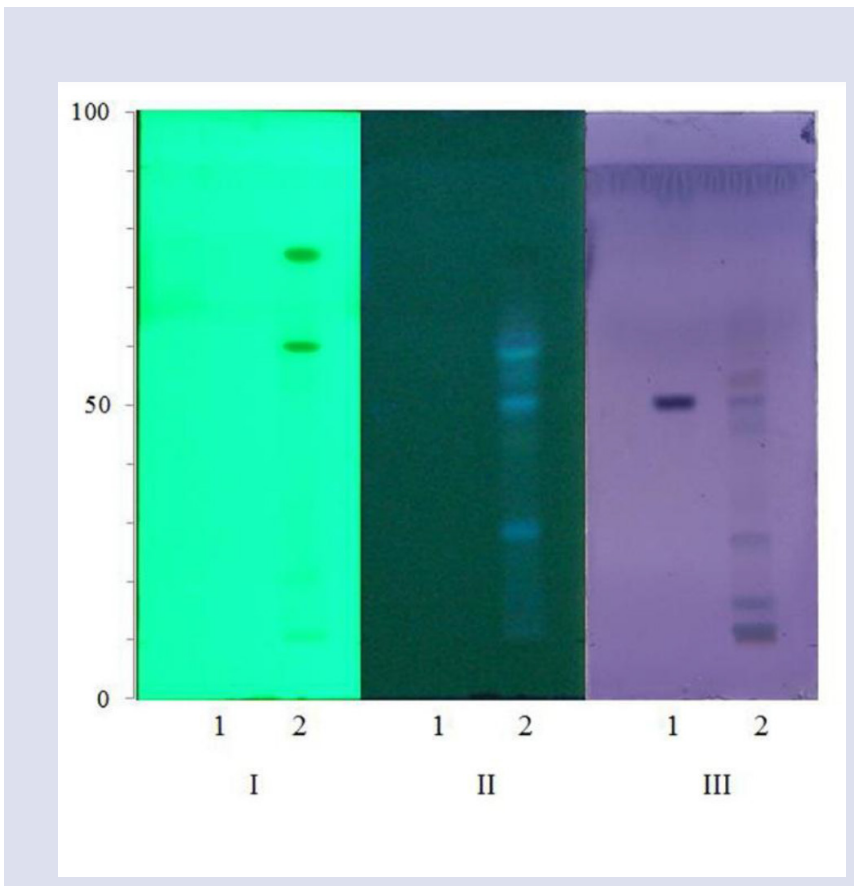

Figure 5: Thin layer chromatography (TLC) chromatogram of daucosterol (1) and dichloromethane extract of $E$. acoroides rhizome (2), detected by UV 254 (I), UV 366 (II) and Anisaldehyde - sulfuric acid spray reagent (III).

Table 2: The $h R_{f}$ values of chemical components in dichloromethane extract of $E$. acoroides rhizome.

\begin{tabular}{ccccc}
\hline \multirow{2}{*}{ Spot } & $\mathbf{h R}_{\mathbf{f}}$ & UV 254 & UV 366 & AnisaldehydeTS \\
\cline { 3 - 5 } & & - & - & Blue \\
1 & $2-5$ & - & - & Blue \\
2 & $7-8$ & - & - & Blue \\
3 & $20-21$ & - & Blue & - \\
4 & $21-23$ & - & Blue & Dark purple \\
5 & $50-52^{*}$ & - & - & Brick red \\
6 & $53-56$ & - & Green & - \\
7 & $58-59$ & Quenching & Blue & - \\
8 & $60-62$ & Quenching & - & - \\
9 & $81-83$ & Q
\end{tabular}

*daucosterol

which corresponded with a spot of E. acoroides extract at $h_{\mathrm{f}} 50-52$. These TLC chromatograms are characteristic and help identification of the E. acoroides rhizome.

For HPLC analysis of E. acoroides, the mobile phase was developed using gradient of acetonitrile and $0.05 \%$ trifluoroacetic acid in water starting from 0:100, 5:95, 12:88, 15:85, 15:85, 25:75, 35:65, 45:55, 60:40, 60:40, $100: 0$ and $100: 0$ at $0,5,15,25,35,40,50,60,80,90,100$ and $120 \mathrm{~min}$, respectively, with a flow rate of $0.8 \mathrm{~mL} / \mathrm{min}$. The HPLC chromatogram of E. acoroides was shown in the Figure 6 . The active ingredients, apigenin and luteolin appeared at retention time of 49.35 and $45.83 \mathrm{~min}$, respectively. This HPLC chromatogram is used as a fingerprint for identification of the E. acoroides rhizome. 


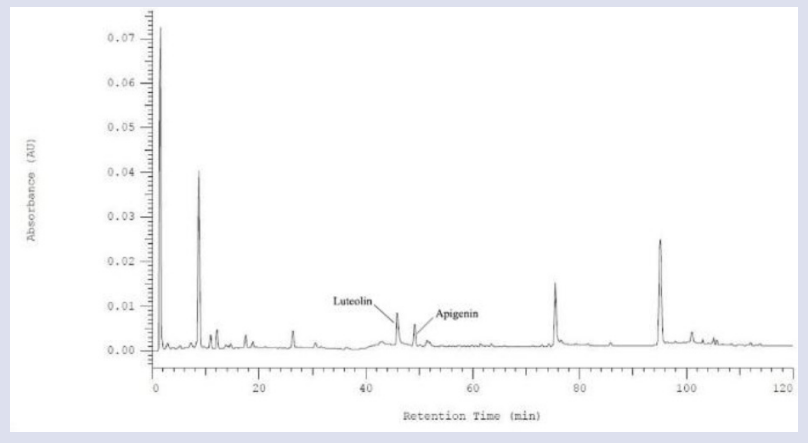

Figure 6: High performance liquid chromatography (HPLC) chromatogram of $80 \%$ ethanol extract of E. acoroides rhizome detected at UV 254.

\section{DISCUSSION}

Therapeutic values and the chemical compounds found in crude drug materials are usually variable and depend on many factors. Pharmacognostic and physicochemical standards are two important approaches to quality control for medicinal plants. Macroscopical and microscopical study and chemical identification by TLC and HPLC analysis of all samples collected from 19 traditional drug stores were compared to authentic samples and all were found to be similar. We can be confident that all samples used in this study were rhizomes of E. acoroides. The morphology of E. acoroidesis fairly characteristic. The rhizome is black and clothed with numerous black fibrous strands of decayed leaves and roots. E. acoroides is the largest of seagrasses and is very distinctive and unlikely to be confused with any other species. This situation is quite different from other studies which usually found that more than one species was being sold under the same name in the market. ${ }^{23-24}$ Microscopical studies indicated the presence of vessels, fiber, parenchyma cells, sclereid, tracheid and trichome which are characteristics of the plant.

Chemical identification by TLC or HPLC fingerprint is one of the standard methods to confirm species of plant. The TLC chromatogram of E. acoroides detected by anisaldehyde-sulfuric acid spray reagent showed 5 spots including three blue spots, dark purple spot and brick red spot at $h_{\mathrm{f}} 2-5,7-8,20-21,50-52$ and 53-56, respectively. The major compound was daucosterol at $\mathrm{hR}_{\mathrm{f}} 50-52$ which is the chemical marker for identification of $E$. acoroides. HPLC fingerprint showed typical characteristic for identification of E. acoroides. The active ingredients, apigenin and luteolin were also detected at retention time of 49.35 and $45.83 \mathrm{~min}$, respectively.

Identification of substitution and adulteration in medicinal plants by determination of total ash and acid-insoluble ash are standard specification requirements in pharmacopeia. Normally, total ash and acid-insoluble ash values in medicinal plants are in the range of 1-20\% and $1-10 \%$, respectively. ${ }^{21}$ The average of total ash and acid-insoluble ash value of E. acoroides were found at 20.55 and $5.64 \%$, respectively. Total ash and acid-insoluble ash value can indicate adulteration of the presence of impurities. ${ }^{25}$ Total ash is also correlated with physiological ash of medicinal plants. In our study case, both total ash and acid-insoluble ash were comparatively high, as might occur if the rhizome of E. acoroides was contaminated with sand and absorbed mineral in the sea. This suggestion was confirmed by studying amount of metals concentrations (As, $\mathrm{Cd}, \mathrm{Cu}, \mathrm{Hg}$ and $\mathrm{Pb}$ ) in E. acoroides at Pulai River Estuary, Johor
Straits, Malaysia. They found that $\mathrm{Pb}$ was the highest contaminant in E. acoroides $(202 \pm 102 \mu \mathrm{g} / \mathrm{g} \mathrm{DW}$ (dried weight) follow by $\mathrm{Cd}, \mathrm{Hg}$, As $52 \pm 44,46 \pm 41,16 \pm 21,10.52 \pm 10.09 \mu \mathrm{g} / \mathrm{g}$ DW, respectively. This indicates that $E$. acoroides is a species possessing the capabilities to uptake metals from sediment. ${ }^{26}$

The percentage water soluble extractive of E. acoroides was obtained the highest amount. This result showed that most components of E. acoroides rhizome were soluble in water which corresponded with previous literature reports. Most chemical compounds of E. acoroides rhizome are glycosides which have high polarity and are soluble in water. ${ }^{16,27}$

The limitation of each physicochemical parameter was specified following the guidelines of the World Health Organization and Thai herbal pharmacopeia by average of each physicochemical value plus or minus of $10 \%$. The physicochemical parameters of E. acoroides rhizomes, viz. foreign matter, loss on drying, total ash content and acid-insoluble ash content could be specified as not more than $0.25,3.50,23.00$ and $6.20 \%(w / w)$, respectively while ethanol, water, hexane and chloroform soluble extractive were not less than $2.30,14.80,4.10$ and $4.10 \%(w / w)$, respectively.

\section{CONCLUSION}

The present study on macroscopic, microscopic and physicochemical properties of $E$. acoroides rhizome provides useful information that could serve as a diagnostic tool for the standardization of $E$. acoroides and will be helpful in characterization of the crude drug in the market. This information provides identifying parameters to substantiate and authenticate the E. acoroides as a part of the pharmacopoeia.

\section{ACKNOWLEDGEMENT}

This study was fully funded by the agricultural research development agency (public organization) grant number 984-3-58874-6. We express our sincere thanks to Dr. Sutthira Sedlak, the botanist of Walairukhavej Botanical Research Institute, Mahasarakham University for plant identification and Mr. Adrian Roderick Plant, Mahasarakham University for English improvement.

\section{CONFLICT OF INTEREST}

The authors declare no conflicts of interest.

\section{ABBREVIATIONS}

As: Arsenic; Pb: Lead; Cd: Cadmium; Cu: Copper; Hg: Mercury; cm: Centimeter; g: Gram; h: Hour; m: Meter; min: Minute; mm: Millimeter; $\mu \mathrm{m}$ : Micrometer; w/w: Weight/weight; $\mathbf{m g} / \mathbf{m L}$ : Milligram/milliliter; $\boldsymbol{\mu g}$ /g: Microgram/gram; ${ }^{\circ} \mathbf{C}$ : Degree celsius; $\mathbf{R}_{\mathbf{f}}$ : Retention factor; $\mathbf{h R}_{\mathbf{f}}: 100$ Rf; AR: Analytical reagent; DW: Dried weight; TLC: Thin layer chromatography; HPLC: High performance liquid chromatography.

\section{REFERENCES}

1. Hartog CD, Kuo J. Taxonomy and biologeography of seagrasses. In: Lakrum AWD, Orth RJ, Duarte CM. Seagrasses: biology, ecology and conservation. Berlin: Springer. 2006;1-23

2. McRoy $C P$, Helfferich $C$. Seagrass ecosystem: A scientific perspective. New York Marcel Dek-ker. 1977.

3. The United Nations environment programme (UNEP). Seagrass in the South China Sea. Bangkok: The United Nations environment programme. 2004

4. Green EP, Short FT. Editors World atlas of seagrasses. Berkeley: University of California Press. 2003.

5. Bell JD, Pollard DA. Ecology of fish assemblages and fisheries associated with seagrasses. In: Larkum AWD, McComb AJ, Shepherd SA, Editors. Biology of seagrasses: a treatise on the biology of seagrasses with special reference to the Australasian region. Amsterdam: Elsevier 1989;565-609.

6. Livingston RJ. Trophic response of fishes to habitat variability in coastal seagrass systems. Ecology. 1984;65(4):1258-75. 
7. Phillips RC, McRoy CP, Editors. Handbook of seagrass biology: An ecosystem perspective. New York and London: Garland STPM Press. 1980.

8. Montaño NME, Bonifacio RS, Rumbaoa RGO. Proximate analysis of the flour and starch from Enhalus acoroides (L.f) Royle seeds. Aquat Bot. 1999;65(1-4):321-5.

9. de la Torre-Castro M, Rönnbäck P. Links between humans and seagrasses-an example from tropical East Africa. Ocean Coast Manag. 2004;47(7-8):361-87.

10. Raja KRR, Arumugam R, Anantharaman P. In vitro antioxidant activities of ethanol extract from Enhalus acoroides (L.F.) Royle. Asian Pac J Trop Biomed. 2010;3(11):898-901.

11. Nindatu M, Noya F, Seimahuira T, Kaya E, Wakano D, Leasa M. Potential of Lamun (Enhalus acoroides) seeds from west seram coastal area as natural antioxidant. Res J Pharm Biol Chem Sci. 2016;7(2):66-71.

12. Phichiansunthon $C$, Chawalit M, Chirawong W. Explanation of a Thai traditional textbook, O-sot-pranarai. Bangkok: Amarin. 2015

13. Wuthidhammvej W. Herbal encyclopedia and a theory of Thai traditional pharmacy. Bangkok: O.A. Printing.1997.

14. Tiyaworanant S, Picheansoonthon $C$. The inscriptions of herbal formulas at Wat Ratcha-orasaram Ratchaworawihan. Khon Kaen: Khon Kaen University. 2016.

15. Department of Thai traditional and alternative medicine. Textbook of Thai traditional medicine in the inscriptions at Wat Phrachetuphon Wimonmangkhalaram (Wat Pho). Bangkok: The printing office of the war veterans organization of Thailand. 2014.

16. Qi SH, Zhang S, Qian PY, Wang BG. Antifeedant, antibacterial and antilarval compounds from the South China Sea seagrass Enhalus acoroides. Botanica Marina. 2008;51(5):441-7.

17. Alam K, Agua T, Maven H, Taie R, Rao KS, Burrows I, et al. Preliminary screening of seaweeds, seagrass and lemongrass oil from Papua New Guinea for antimicrobial and antifungal activity. Int J Pharmacogn. 1994;32(4):396-9.

18. Gillan FT, Hogg RW, Drew EA. The sterol and fatty acid compositions of seven tropical seagrasses from North Queensland, Australia. Phytochemistry. 1984;23(12):2817-21.

19. Department of Medical Sciences, Ministry of Public Health. Thai herbal pharmacopoeia 2016. $1^{\text {st }}$ edition. Bangkok: The agricultural co-operative federation of Thailand. 2016.

20. Thitikornpong W, Ongpipattanakul B, Palanuvej C, Ruangrungsi N. Pharmacognostic specification and mangiferin content of Aquilariacrassna Leaves. Pharmacog J. 2017;10(2):293-8.

21. World Health Organization. Quality control methods for herbal materials. Malta: World Health Organization. 2011.

22. Flora of China, www.eFloras.org [database on the Internet]. cited2017, July 9. Available from: http://www.efloras.org/florataxon.aspx?flora_id=2\&taxon_id=10426.

23. Braz R, Wolf LG, Lopes GC, de Mello JC. Quality control and TLC profile data on selected plant species commonly found in the Brazilian market. Rev Bras Farmacogn. 2012;22(5):1111-8.

24. Liang $Y Z$, Xie P, Chan K. Quality control of herbal medicines. J Chromatogr $B$. 2004;812(1-2):53-70.

25. Kibwage IO, Mwangi JW, Thoithi GN. Quality control of herbal medicines. East Cent Afr J Pharm Sci. 2005;8(2):27-30.

26. Ahmad F, Azman S, Said MIM, Baloo L. Biomonitoring of metal contamination in estuarine ecosystem using seagrass. JEHSE. 2015;13(1):1-4.

27. Iwashina T. The structure and distribution of the flavonoids in plants. J Plant Res 2000;113(3):287-99

\section{GRAPHICAL ABSTRACT}

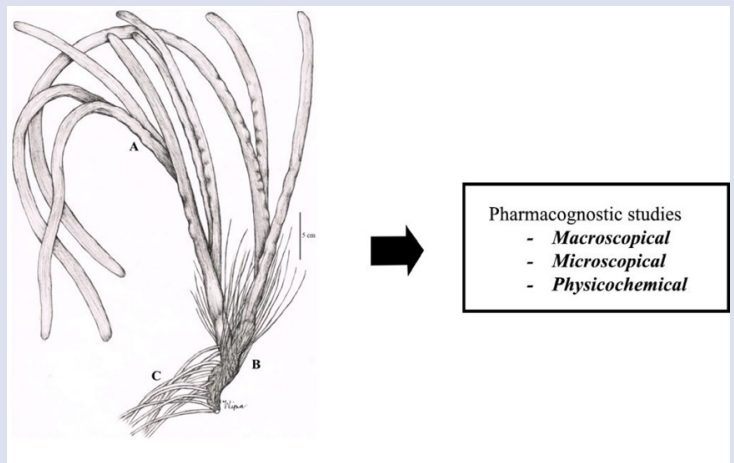

\section{SUMMARY}

- The present study provides useful information for standardization and characterization of $E$. acoroides in the market.

Cite this article: Klangprapun S, Buranrat B, Caichompoo W, Nualkaew S. Pharmacognostical and Physicochemical Studies of Enhalus acoroides (L.F.) Royle (Rhizome). Pharmacog J. 2018;10(6)Suppl:s89-s94. 